University of Nebraska - Lincoln

DigitalCommons@University of Nebraska - Lincoln

Faculty Publications from the Harold W. Manter Laboratory of Parasitology

10-1992

\title{
Parasites of the Extinct Shasta Ground Sloth, Nothrotheriops shastensis, in Rampart Cave, Arizona
}

\author{
Gerald D. Schmidt \\ university of Northern Colorado \\ Donald W. Duszynski \\ University of New Mexico, eimeria@unm.edu \\ Paul S. Martin \\ University of Arizona
}

Follow this and additional works at: https://digitalcommons.unl.edu/parasitologyfacpubs

Part of the Parasitology Commons

Schmidt, Gerald D.; Duszynski, Donald W.; and Martin, Paul S., "Parasites of the Extinct Shasta Ground Sloth, Nothrotheriops shastensis, in Rampart Cave, Arizona" (1992). Faculty Publications from the Harold W. Manter Laboratory of Parasitology. 181.

https://digitalcommons.unl.edu/parasitologyfacpubs/181

This Article is brought to you for free and open access by the Parasitology, Harold W. Manter Laboratory of at DigitalCommons@University of Nebraska - Lincoln. It has been accepted for inclusion in Faculty Publications from the Harold W. Manter Laboratory of Parasitology by an authorized administrator of DigitalCommons@University of Nebraska - Lincoln. 


\title{
PARASITES OF THE EXTINCT SHASTA GROUND SLOTH, NOTHROTHERIOPS SHASTENSIS, IN RAMPART CAVE, ARIZONA
}

\author{
Gerald D. Schmidt*, Donald W. Duszynski, and Paul S. Martin† \\ Department of Biology, The University of New Mexico, Albuquerque, New Mexico 87131
}

\begin{abstract}
Of 7 dissected dung balls of the extinct Shasta ground sloth (Edentata) from Rampart Cave, Arizona, $4(57 \%)$ were found to contain nematode juveniles, helminth eggs, and/or coccidian oocysts. One dung ball was radiocarbon dated at $10,500 \pm 180 \mathrm{yr}$, about the time of ground sloth extinction. It is supposed that the parasites also are extinct. Agamofilaria oxyura n. sp. is proposed for first-stage juveniles of an oxyurid. These juveniles measured 13-20 × 126-198 (16.8 × 159) $\mu \mathrm{m}$. Strongyloides shastensis $\mathrm{n}$. sp. is reported as first-stage juveniles, some of which clearly are molting. These juvenile worms were 23-27 $\times 270-345(24.4 \times 305.3) \mu \mathrm{m}$. Operculated schistosomelike eggs, each with an abopercular point, were 33-50 × 63-90 (43.0 $\times 81.9) \mu \mathrm{m}$. A second type of object that resembled a helminth egg had a thick wall and was 11-14 $\times 13-18(13.5 \times 15.5) \mu \mathrm{m}$. A new collective genus, Archeococcidia, is proposed to include 2 new fossil oocysts. Archeococcidia antiquus $\mathrm{n}$. sp. was the most abundant form found. Its unsporulated oocysts were 19-21 $\times 21-23(19.6 \times 22.1) \mu \mathrm{m}$, and its outer wall bore punctations. Unsporulated oocysts of Archeococcidia nothrotheriopsae n. sp. were spheroidal, 31-35 (33.8) $\mu \mathrm{m}$ wide, and had a smooth outer surface.
\end{abstract}

Parasites of prehistoric extinct mammals rarely are reported. Horne (1985) and Wilke and Hall (1975) provided annotated bibliographies on the analyses of ancient feces, mainly of human origin, and Fry and Moore (1969) found Enterobius sp. in dry human coprolites up to $10,000 \mathrm{yr}$ in radiocarbon age. The fossil dung of some mammals, especially pack rats (Neotoma), is found in abundance in certain dry caves of the North American desert southwest, where ancient feces may endure for tens of thousands of years (Betancourt et al., 1990). Occasionally, dung of certain extinct mammals is also preserved, including entire and fragmentary boluses of the Shasta ground sloth, Nothrotheriops shastensis. One of several giant (extinct) edentates of the Western Hemisphere during the late Pleistocene Epoch, its last remains can be traced to about $11,000 \mathrm{yr}$ ago (Martin et al., 1985) when Shasta ground sloths disappeared along with mammoths, sabertooths, and other megafauna (Martin, 1987). Examination of these dried boluses can offer insight about the parasites that these mammals maintained.

\section{MATERIALS AND METHODS}

We examined 7 sloth dung balls collected from Rampart Cave, Arizona, at the western end of the Grand Canyon. The cave is about $7 \mathrm{~km}$ from Pierce's Ferry

Received 30 July 1991; revised 17 October 1991; accepted 17 October 1991.

* Department of Biological Sciences, University of Northern Colorado, Greeley, Colorado 80631 (deceased).

$\dagger$ Department of Geosciences, University of Arizona, Tucson, Arizona 85721. at the top of a talus slope, more than $200 \mathrm{~m}$ above the level of the Colorado River. Passageways extend roughly $100 \mathrm{~m}$ into limestone (upper Cambrian Period). About $220 \mathrm{~m}^{2}$ of dung, reaching a maximum depth of $1.5 \mathrm{~m}$, covers the floor of part of the cave. Two-thirds of this was destroyed by a smoldering fire between July 1976 and March 1977. Exact provenience of the dung balls in this study is unknown; they were obtained from heaps of dung in back dirt left by the 1940 excavation of Remington Kellogg (Martin, unpubl.).

Portions of each dung ball were broken up and rewetted for $48 \mathrm{hr}$ in a $0.5 \%$ solution of trisodium phosphate, then filtered through coarse cheesecloth, and later through $40-$ and $60-$ mesh brass screens. Aliquots of the resulting filtrate then were examined either directly as wet mounts or they were concentrated by flotation with a concentrated sucrose solution (specific gravity 1.15 ). Parasites and parasite stages were measured with an ocular micrometer and photographed with Panatomic-X 35-mm film within a Zeiss Universal Photomicroscope equipped with both brightfield (Neofluar) and Nomarski-interference $100 \times$ objectives. All measurements are in micrometers $(\mu \mathrm{m})$ with the means given in parentheses following the ranges. Phototypes (Bandoni and Duszynski, 1988) of the coccidian oocysts and both phototypes and syntypes of the worms have been deposited in the U.S. National Museum Parasite Collection (USNMPC), Beltsville, Maryland.

\section{RESULTS}

The dung balls are large, up to $12 \mathrm{~cm}$ and occasionally more than $20 \mathrm{~cm}$ in diameter, lobate, with a reddish-brown varnish of dried mucus. Evidently the animal was totally herbivorous; according to Hansen (1978), the identifiable plant tissues in the dung consist principally of globemallow, Sphaeralcea; Mormon tea, Ephed$\mathrm{ra}$; and cactus, Opuntia. These xeric plants remain important in the regional vegetation of the 
area especially at higher elevation. Vegetation in the immediate vicinity of the cave during the sloth's occupancy included juniper (Juniperus), ash (Fraxinus), and other woodland species that only occur now at higher elevations (Phillips, 1984). Indeed, there is no indication that the climate and vegetation were much different then now. One dung ball, containing unsporulated coccidian oocysts and schistosomelike eggs, has been ${ }^{14} \mathrm{C}$-dated at $10,500 \pm 180 \mathrm{yr}$; the other 3 infected samples were not dated. The weighted average of the youngest 10 samples of dung deposited in the cave was within a few years of 11,000 BP (before present) (Martin et al., 1985). All specimens are presumed to be of this age or greater.

Parasites were found in 4 of the 7 (57\%) samples. There were juveniles of 2 nematode species, 2 morphotypes of coccidian oocysts, and eggs of 2 helminth species. Fungal spores and pollen were abundant and had to be differentiated from possible oocysts. The condition of the nematodes precluded detailed observations and measurements.

The International Code of Zoological Nomenclature (Art. 42 (b)(i)) (Ride et al., 1985: 83) makes provision for "... certain assemblages of taxonomic convenience known as 'collective groups'." Included are species known only from fossil traces (ichnotaxa) and those known only from immature specimens, adult forms of which cannot be determined. Any of those can be reallocated to the correct genus if it is later discovered. Examples given are Agamodistomum Stossich, 1892 (Trematoda), Agamofilaria Stiles, 1907 (Nematoda), and Stelloglyphus Vyalov, 1964 (trace fossil), among others. Presumably, the frequent use of "agamo" as a prefix to these collective group genera stems from its derivation: $a$ - (Gr., not, without) and gam- (Gr., marriage). In applying names to the organisms we found, we sought to follow this basic concept.

Numerous bodies, presumably helminth eggs representing 2 species, were found in 3 dung balls. One kind (Fig. 9) is conspicuously pointed at 1 end and may have a subterminal operculum at the other. The outer surface of the egg capsule is pitted (Fig. 10). Except for the operculum, these eggs look somewhat like schistosome eggs. These eggs were found in 3 of the 7 dung balls and measured $(n=8) 33-50 \times 63-90(43.0 \times 81.9)$.

A second type of object that resembled a helminth egg was found in only 1 of the dung balls. Its thick wall gives some resemblance to a tox- ascarid egg (Fig. 11), but the outer layer is smooth and its size is much smaller $(\mathrm{n}=8), 10.8-14.4$ $\times 12.6-18.0(13.5 \times 15.5)$.

\section{Agamofilaria oxyura n. sp.}

(Figs. 1-3)

Description: Robust worms, usually tightly coiled, resembling first-stage pinworms (Fig. 1). Mouth surrounded by 3 bilobed lips (Fig. 2); tail sharply pointed (Fig. 3). Posterior end of esophagus expanded into a bulb, characteristic of the order (Fig. 1, arrow). Length $(\mathrm{n}=7)$ 13-20 × 126-198 (16.8 × 159).

\section{Taxonomic summary}

Type host: Shasta ground sloth, $N$. shastensis.

Type locality: Rampart Cave, ca. $7 \mathrm{~km}$ upstream from Pierce's Ferry, 36 $06^{\prime} \mathrm{N}, 113^{\circ} 56^{\prime} \mathrm{W}$, Grand Canyon, Arizona.

Material deposited: Phototype of representative structures from 1 juvenile worm and 10 syntypes in the USNMPC No. 82076.

\section{Remarks}

One dung ball contained many nematode juveniles (about 10 worms/drop of sediment) that resemble firststage pinworms. Adult nematodes were not found, suggesting that this does not represent a coprophagous, free-living form. This species was found in only 1 of the 7 dung balls examined.

\section{Strongyloides shastensis $\mathbf{n}$. sp. (Figs. 4-8)}

Description: Slender worms, only slightly coiled (Fig. 4). Head small, lacking conspicuous lips. Esophagus usually detached from mouth and difficult to interpret (Fig. 5); in some specimens in which not detached from mouth, a pair of rodlike structures are present (Fig. 6). Esophagus thicker at junction with intestine, representing a pseudobulb. Tail (Fig. 7) long and pointed, resembling a first-stage juvenile of Strongyloides. Some worms in process of molting (Fig. 8). Length $(n=7)$ 23-27 × 270-349 (24.4 × 305.3).

\section{Taxonomic summary}

Type host: Shasta ground sloth, $N$. shastensis.

Type locality: Rampart Cave, ca. $7 \mathrm{~km}$ upstream

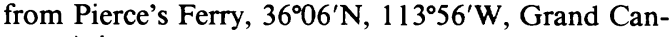
yon, Arizona.

Material deposited: Phototype of representative structures from 1 juvenile worm and about 10 syntypes in the USNMPC No. 82075.

\section{Remarks}

One dung ball contained numerous nematode juveniles that bear striking similarities to juvenile Strongyloides. Adult nematodes were not found, suggesting that these specimens do not represent a coprophagous, free-living form. This species was found in 2 of the 7 dung balls examined.

\section{Archeococcidia n. gen.}

Reserved for structures that are oocystlike in general size, shape, and appearance; that come 


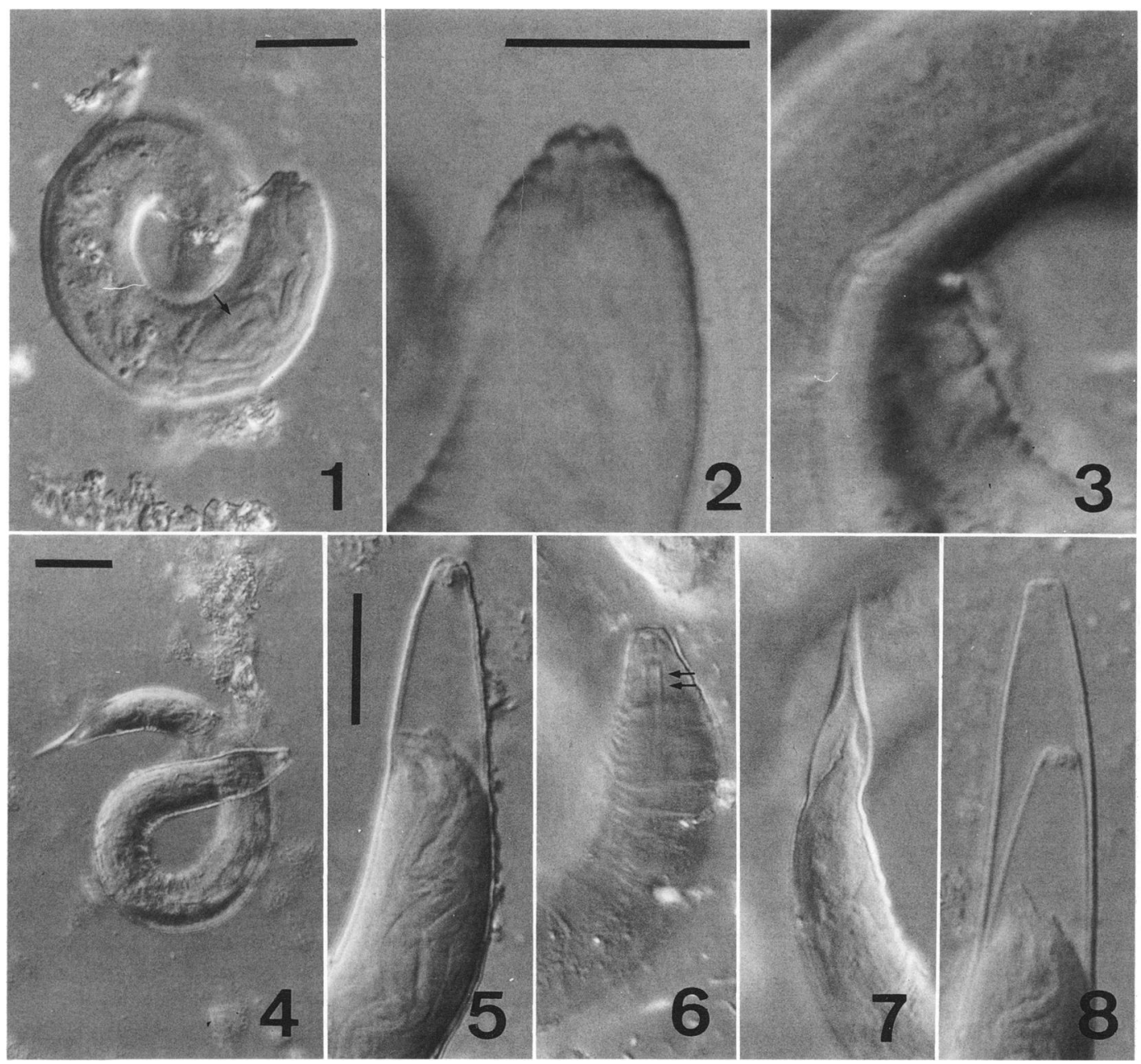

FIGURES 1-8. Photomicrographs of juvenile nematodes extracted from the desiccated feces of the extinct Shasta ground sloth, Nothrotheriops shastensis, from Rampart Cave, Grand Canyon, Arizona. Figures 1-3, bars $=15 \mu \mathrm{m}$; Figures $4-8$, bars $=30 \mu \mathrm{m}$. 1. Lateral view of entire juvenile of Agamofilaria oxyura n. sp.; note esophageal bulb (arrow). 2. Enlarged head of $A$. oxyura showing 3 bilobed lips of mouth. 3. Pointed tail of same species. 4. Lateral view of entire juvenile of Strongyloides shastensis $\mathbf{n}$. sp.; note pointed tail and esophagus pulled away from mouth. 5. Enlargement of anterior end of $S$. shastensis juvenile; note how esophagus is detached from mouth. 6. Anterior ends of some $S$. shastensis juveniles show 2 rodlike structures (arrows) seen only when the esophagus has not separated from the mouth. 7. Enlarged lateral view of tail showing location of anus. 8. Same species showing molting to second stage.

from dried, petrified, or mummified feces or bodies of extinct animals; and that, because of their antiquity, are unsporulated and, therefore, not able to be placed into an appropriate genus.

\section{Archeococcidia antiquus n. sp.}

(Figs. 12, 13)

Description: Unsporulated coccidian oocysts ellipsoidal with pitted outer wall (Fig. 13) $(n=8) 19-21 \times$ 21-23 (19.6 × 22.1). Inner mass disrupted, no indication of sporocyst formation could be seen, and thus, it is impossible to place it in any known genus.

\section{Taxonomic summary}

Type host: Shasta ground sloth, $N$. shastensis.

Type locality: Rampart Cave, ca. $7 \mathrm{~km}$ upstream from Pierce's Ferry, 3606'N, $113^{\circ} 56^{\prime} \mathrm{W}$, Grand Canyon, Arizona.

Material deposited: Phototype of unsporulated oocyst in the USNMPC No. 82073.

\section{Remarks}

An abundance of unsporulated coccidian oocysts (Fig. 12) was found in 1 dung ball. It is likely an eimerian as all known coccidians described from edentates to 


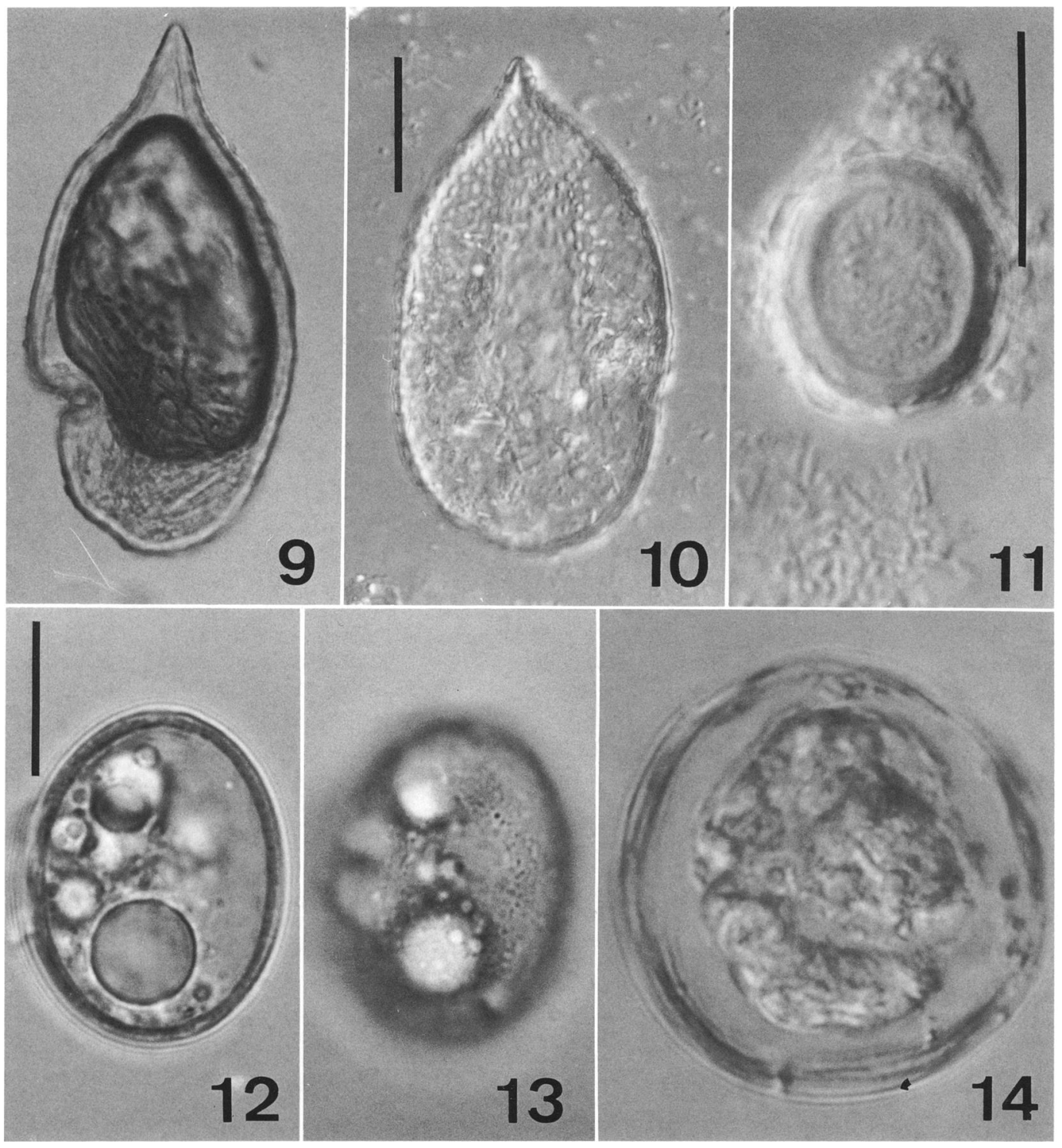

FIGURES 9-14. Photomicrographs of helminth eggs (Figs. 9-11) and unsporulated coccidian oocysts (Figs. 12-14) extracted from the desiccated feces of the extinct Shasta ground sloth, Nothrotheriops shastensis, from Rampart Cave, Grand Canyon, Arizona. Figures 9, 10, bar $=20 \mu \mathrm{m}$; Figure 11, bar $=15 \mu \mathrm{m}$; Figures 12-14, bar $=10 \mu \mathrm{m}$. 9. Schistosomelike egg; dark interior is an air bubble and the marginal groove is artifactual. 10 . Same species, showing pitted outer surface. 11. Thick-walled toxascaridlike egg; note thick outer wall and small size. 12. Unsporulated oocyst of Archeococcidia antiquus n. sp. 13. Same species; note the sculptured surface. 14. Unsporulated oocyst of Archeococcidia nothrotheriopsae n. sp.; note large size.

date are either eimerians or sarcocystans (Pellérdy, 1974; Levine, 1988); however, because sporocyst formation was not evident, we elect to place this form in our new genus. Each species in a collective group takes its original author and date, but no type species is required. Although not required, we elect to designate $A$. antiquus as the type species. Oocysts of this form were found in only 1 of the 7 dung balls examined.

\section{Archeococcidia nothrotheriopsae n. sp.}

(Fig. 14)

Description: Unsporulated coccidian oocysts spheroidal, $31-35(33.8, n=4)$ wide, with smooth outer surface. Undifferentiated sporoblast conspicuous (Fig. 14). 


\section{Taxonomic summary}

Type host: Shasta ground sloth, $N$. shastensis.

Type locality: Rampart Cave, ca. $7 \mathrm{~km}$ upstream from Pierce's Ferry, 36 $06^{\prime} \mathrm{N}, 113^{\circ} 56^{\prime} \mathrm{W}$, Grand Canyon, Arizona.

Material deposited: Phototype of unsporulated oocyst in the USNMPC No. 82074.

\section{Remarks}

A second kind of oocyst, not as common as $A$. antiquus, was found in another dung ball. Oocysts of this form were found only in 1 of the 7 dung balls examined In summary, 4 of $7(57 \%)$ dung balls from the extinct Shasta ground sloth from Rampart Cave, Arizona, had parasite stages in them. One dung ball had only a few juveniles of $S$. shastensis. Another had oocysts of $A$ antiquus (Figs. 12, 13) and schistosomelike eggs (Figs. $9,10)$. A third ball had many juveniles of $S$. shastensis (Figs. 4-8) and both schistosomelike and small, thickwalled eggs (Fig. 11). The fourth infected dung ball had oocysts of $A$. nothrotheriopsae (Fig. 14), schistosomelike eggs, and juveniles of $A$. oxyura (Figs. 1-3).

\section{DISCUSSION}

Paleoparasitology is attracting an increasing number of investigations (Kliks, 1983, 1990; Reinhard et al., 1987; Ferreira et al., 1991). For annotated bibliographies, see reports by Häntzschell et al. (1968), Gooch (1973), Wilke and Hall (1975), and Horne (1985). Nearly all previous reports have been on human, or presumably human, materials.

Two reports are known to us concerning parasites of sloths from the Pleistocene Epoch. Ringuelet (1957) described "probable remains of nematode eggs" from dung of the giant sloth, Mylodon listai, in Tierra del Fuego, Chile. The eggs were elliptical, $31.5-49.5 \times 18.7-29.2$ in size.

Laudermilk and Munz (1938) studied dung balls of "Nothrotherium" $(=N$. shastensis $)$ also from Rampart Cave. Although their paper was concerned with the plants making up the dung balls, they reported, “... perfectly preserved nematode worms as well as their eggs were abundant." Remains of their material are not known to exist. This is the only previous report of parasites of $N$. shastensis. Further studies probably would uncover other parasite remains, and a detailed chronological sequence might be of interest to those seeking causes of extinction.

\section{ACKNOWLEDGMENT}

Thanks are due Norman D. Levine, Professor Emeritus, The University of Illinois, who looked at photomicrographs of our unsporulated oocysts and gave his opinion that he too thought they were oocysts and that we should publish this information.

\section{LITERATURE CITED}

BANDONI, S. M., AND D. W. DuszYNSKI. 1988. A plea for improved presentation of type material for coccidia. Journal of Parasitology 74: 519-523.

Betancourt, J. L., T. R. van Devender, AND P. S. MARTIN. 1990. Packrat middens: The last 40,000 years of biotic change. University of Arizona Press, Tucson, $468 \mathrm{p}$.

Ferreira, L. F., A. Araujo, U. Confalonieri, M. Chame, And D. C. Gomes. 1991. Trichuris eggs in animal coprolites dated from 30,000 years ago. Journal of Parasitology 77: 491-493.

FRY, G. F., AND J. G. MOORE. 1969. Enterobius vermicularis: 10,000-year-old human infection. Science 166: 1620.

Gooch, P. S. 1973. Helminths in archaeological and pre-historic deposits. Commonwealth Institute of Helminthology, Annotated Bibliography No. 9, St Albans, Herts, England, 8 p.

HANSEN, R. M. 1978. Shasta ground sloth food habits, Rampart Cave, Arizona. Paleobiology 4: 302 319.

Häntzschell, W., F. El-Baz, and G. C. Amstutz. 1968. Coprolites: An annotated bibliography. Memoirs of the Geological Society of America 108: 1-132.

HORNE, P. D. 1985. A review of the evidence of human endoparasitism in the pre-Columbian New World through the study of coprolites. Journal of Archaeological Science 12: 299-310.

KLIKs, M. M. 1983. Paleoparasitology: On the origins and impact of human-helminth relationships. $\mathrm{Hu}$ man Ecology and Infectious Diseases 11: 291-313.

- 1990. Helminths as heirlooms and souvenirs: A review of New World paleoparasitology. Parasitology Today 6: 93-100.

LAudermilk, J. D., AND P. A. Munz. 1938. Plants in the dung of Nothrotherium from Rampart and Muav Caves, Arizona. Carnegie Institution of Washington, Publication No. 487: 271-281.

LeVINE, N. D. 1988. The protozoan phylum Apicomplexa, Vol. I. CRC Press, Inc., Boca Raton, Florida, 203 p.

MARTIN, P. S. 1987. Late Quaternary extinctions: The promise of TAMS ${ }^{14} \mathrm{C}$ dating. In Proceedings of the fourth international symposium on acceleration mass spectrometry, H. Gove, A. E. Litherland, and D. L. Moore (eds.). Nuclear instruments and methods in physics research B29. North Holland Publishing Company, Amsterdam, p. 179_ 186.

, R. S. Thompson, AND A. LoNG. 1985. Shasta ground sloth extinction: A test of the blitzkrieg model. In Environments and extinctions: Man in late glacial North America, J. I. Mend and D. Meltzer (eds.). Center for the Study of Early Man, Orono, Maine, p. 5-14.

Pellérdy, L. P. 1974. Coccidia and coccidiosis, 2nd ed. Verlag Paul Parey, Berlin, 959 p.

Phillips, A. M. 1984. Shasta ground sloth extinction: Fossil packrat midden evidence from the western Grand Canyon. In Quaternary extinctions: A pre- 
historic revolution, P. S. Martin and R. G. Klein (eds.). University of Arizona Press, Tucson, Arizona, p. 148-158.

$\rightarrow$ Reinhard, K. J., R. H. HeVly, AND G. A. ANDERSON. 1987. Helminth remains from prehistoric Indian coprolites on the Colorado Plateau. Journal of Parasitology 73: 630-639.

Ride, W. D. L., C. W. Sabrosky, G. Bernardi, and R. V. Melville (eds.). 1985. International code of zoological nomenclature, 3rd. ed. H. Charlesworth and Co., Ltd., Huddersfield, England, $338 \mathrm{p}$.
Ringuelet, R. A. 1957. Restos de probables huevos de nematodes en el estiercol del edentado extinguido Mylodon listai (Ameghino). Ameghiniana 1: 15-16.

Wilke, P. J., AND H. J. Hall. 1975. Analysis of ancient feces: A discussion and annotated bibliography. Contribution of the University of California Archeological Research Facility, No. 24, Department of Anthropology, University of California, Berkeley, California, 47 p. 